\title{
Doenças carenciais no período da seca de 1877-1879 na Província do Rio Grande do Norte
}

\section{Diseases in the drought period of 1877-1879 in the province of Rio Grande do Norte}

Avohanne Isabelle Costa de Araújo ${ }^{1}$

Este trabalho tem como objetivo analisar as doenças de ordem carencial que foram registradas durante a seca de 1877-1879 no Rio Grande do Norte. Eu parto desta seca para entender as condições sociais pelas quais as populações viviam, pensando na saúde e nas enfermidades, pois como defendem Durval Muniz de Albuquerque Junior e Paulo Cesar Gonçalves, esta seca se diferencia das anteriores pela visibilidade que a elite política do Norte (atual Nordeste) trouxe em seus discursos, utilizando-a como argumento para conseguir recursos no intuito de combater as secas e as misérias assoladas pela fome nas províncias afetadas (dentre elas, o Rio Grande do Norte), chegando ao patamar de "problema nacional", com seu cortejo de calamidades: falta d'água, de alimentos, dizimação dos rebanhos, elevada mortalidade e epidemias. Outra justificativa em optar por esta delimitação temporal é que, por meio da análise das fontes governamentais, pude encontrar notificações de doenças carenciais como beribéri e escorbuto. No tocante à metodologia, utilizo o cruzamento das fontes, classificação e análise qualitativa das temáticas encontradas na documentação, mapeamento das doenças carenciais que assolavam a população sertaneja do Rio Grande do Norte e produção de tabelas a partir dos dados encontrados nas fontes. Por meio da análise dos Relatórios dos Presidentes de Província do RN, dos jornais e dos relatos de memorialistas que viveram neste período, quero entender a dimensão social dessas doenças a partir das discussões de Anny Jackeline Torres Silveira, Dilene Raimundo do Nascimento e Claudine Herzlich, levando em consideração a dieta alimentar que era consumida pela população sertaneja, as condições econômicas da agricultura, pecuária e a situação da água durante este período. Todos estes aspectos são importantes para refletir sobre as condições de vida e saúde dos retirantes que migravam à procura de alimentos e água, além dos impactos que a fome causava na vida dessa população. Assim, dos resultados colhidos até o presente momento, as doenças mais comuns (além dos surtos epidêmicos) foram de ordem carencial como beribéri e escorbuto, cujo motivo estava relacionado a uma dieta pobre em nutrientes e vitaminas e em virtude dos alimentos que se tornavam escassos durante a seca. Problematizar as doenças carenciais, levando em consideração a sua dimensão social, amplia o olhar dos historiadores para refletir sobre os problemas frequentes de crise alimentícia, as dificuldades no abastecimento dos gêneros alimentícios, a qualidade dos alimentos que existiam disponíveis no comércio das cidades dos sertões do Rio Grande do Norte, a dieta-base da população migrante, as condições de vida e as explicações médicas perante o aparecimento dessas moléstias. Isso nos leva a compreender também o próprio papel do Estado perante as políticas de calamidade que envolviam, principalmente, a seca, a fome e as doenças em fins do século XIX.

Palavras-chave: beribéri; escorbuto; fome; seca; alimentação.

Keywords: beriberi; scurvy; hunger; drought; food. 